\title{
Wolfram Syndrome: Case Report of Two Siblings with Review of Literature
}

\author{
Inderpal Singh Kochar ${ }^{1}$, Rakhi Jain ${ }^{2 *}$ and Smita Ramachandran ${ }^{2}$ \\ ${ }^{1}$ Consultant Pediatric and Adolescent Endocrinology, Indraprastha Apollo Hospital, India \\ ${ }^{2}$ Fellow Pediatric and Adolescent Endocrinology, Indraprastha Apollo Hospital, India
}

Submission: September 29, 2019; Published: October 21, 2019

*Corresponding author: Rakhi Jain, Fellow Pediatric and Adolescent Endocrinology, Indraprastha Apollo Hospital, New Delhi, India

\begin{abstract}
Wolfram syndrome (WS) is an autosomal recessive neurodegenerative disorder. Also known as DIDMOAD it can have variable clinical presentation at different age. We report two siblings with WS presenting at 6 and 5 yrs of age respectively. They presented with type I diabetes mellitus and optic atrophy. Both were compound heterozygotes for mutation on exon 8 of WS1 gene. A high index of clinical suspicion along with genetic analysis plays a key to definite diagnosis.
\end{abstract}

Keywords: Wolfram syndrome; Diabetes mellitus; Optic atrophy

\section{Introduction}

Wolfram syndrome (WS), also known as DIDMOAD (Diabetes insipidus, Diabetes mellitus, Optic atrophy, Deafness), is an autosomal recessive neurodegenerative disorder. It was first described in 1938 by Wolfram and Wagener [1]. Although a rare disease, it is associated with significant morbidity and mortality due to lack of effective treatment to halt, delay or reverse the progression of disease [1]. The major clinical presentation includes Diabetes mellitus, optic atrophy, central diabetes insipidus, sensorineural deafness, urinary tract problems and neurological difficulties. Diabetes mellitus is the usually first manifestation of the disease at the age of 6 years followed by optic atrophy at around 11 years of age [2]. Additional morbidities include hypogonadism, infertility, hypopituitarism [3], cerebellar ataxia, peripheral neuropathy, dementia, psychiatric illness, and urinary tract problems [4-6].

\section{Case report}

We report cases of siblings with DIDMOAD syndrome with the genetic analysis of the mutations of the affected siblings and both the parents.

\section{Case 1}

A 6-year-old male child was brought to the pediatric endocrine department as a case of type 1 diabetes mellitus presenting as diabetic ketoacidosis. Pancreatic autoantibodies including antiglutamic acid decarboxylase antibody, anti-insulin antibody and anti-islet cell antibody, as well as thyroid and celiac antibodies were all negative. He had bilateral optic atrophy with constriction and central scotoma of visual field. Bilateral distance vision was 6/18. Optical Coherence Tomography showed significant retinal nerve fibre layer (RNFL) thinning in both eyes. He complained of bedwetting. Diabetes insipidus was ruled out as serum osmolarity, urinary osmolarity, water deprivation test were normal. Genitourinary tract ultrasound was done to exclude urinary tract anomalies and was found to be normal. He was a product of non-consanguineous marriage. Genetic analysis by clinical sequencing of the WFS1 gene was performed. It showed that he was compound heterozygote for c.1228_1231delCTCT \& c.2265 $\mathrm{T}>\mathrm{A}$ present on exon 8 . Child is currently on insulin therapy and on regular follow-up.

\section{Case 2}

The younger sibling, 5-year-old, male, was brought to the pediatric endocrine department with nonketotic hyperglycemia. He was diagnosed with Type I Diabetes mellitus. He, too, like his elder sibling had optic atrophy but had not developed diabetes insipidus. The investigations showed that anti glutamic acid decarboxylase antibody, antiislet cell antibody, antithyroid antibodies and celiac antibodies were negative. Serum osmolarity and urinary osmolarity were normal. His genetic analysis for mutation in WFS1 gene showed him to bea compound heterozygote for c.1228_1231delCTCT \& c.2265 T>A on exon 8. The child is on 
insulin therapy. Genetic analysis of parents revealed that mother was heterozygous for c.2265T>A while father was heterozygous for c.1228_1231delCTCT.

\section{Discussion and Review of literature}

WS is a rare neurodegenerative disease. It is autosomal recessive in inheritance. Type 1 Diabetes mellitus and optic atrophy are the commonest and earliest presentations of the disease in pediatric age group [7, 8]. Only $14-58 \%$ of all the patients have all the four components of DIDMOAD. Both the cases had optic atrophy which is present in first decade in WS. Suspicion of the diagnosis is usually based on history and clinical manifestations. It must be suspected on observation of optic nerve atrophy after the diagnosis of diabetes mellitus under the age of 16. There is enough evidence to suggest that WS is a spectrum and the genotype phenotype correlation is very distinct as many patients had phenotypic variability [6]. Non autoimmune type 1 diabetes mellitus is present in $98 \%$ of the cases at an average age of about 6 years although it may not be the presenting feature in $20 \%$ [9]. One of our cases presented at 6 years and the other at 5 years with Type 1 Diabetes so the age of presentation in our cases is consistent with the literature [2]. Diabetic ketoacidosis is very rare in wolfram syndrome, but it is the presenting complaint in one of the cases we report. One of them (case 1) had diabetic ketoacidosis which is uncommon in WS. The other (case 2) presented with nonketotic hyperglycemia. In patients of WS, daily insulin requirement is low, glycemic control is better and chances of developing ketoacidosis are less as compared to autoimmine DM. This may be attributed to presence of residual beta cell mass in pancreas [10].

Optic atrophy is present in $82 \%$ at an average age of around 10 11 years. It is significant to screen all children with type 1 DM for optic atrophy for early diagnosis of Wolfram syndrome. Apart from optic atrophy other uncommon ocular anomalies associated with WS are cataract, glaucoma, pigmentary retinopathy, maculopathy, nystagmus. Association of diabetes mellitus and optic atrophy is the best criteria for diagnosis of Wolfram, association of DM with cataract may also be seen [7]. Central Diabetes insipidus may be present in second decade of life with average age 14 years [9]. None of our cases had DI. Urinary tract anomalies may present at 12-20 years of age in about $19 \%$ cases. Apart from these gastrointestinal and psychiatric manifestations, hypogonadism, pituitary insufficiency, cardiac anomalies, infertility, cerebellar ataxia and peripheral neuropathy which are uncommon in pediatric age group were not present in our cases. Studies suggest that patients with genotypes that are likely to lead to absent protein production were more likely to have earlier onset diabetes, and possibly earlier onset optic atrophy, than patients with residual protein expression [9]. Genotype phenotype correlations are less evident for other features.

\section{Pathophysiology of WS}

WFS1 gene maps to chromosome 4p16.1. [11,12]. The function of gene product is to maintain homeostasis in the Endoplasmic
Reticulum (ER). Endocrine cells are very susceptible to ER stress due to their rapid changes in secretory protein expression levels which is found to have a role in $\beta$-cell dysfunction and apoptosis in diabetes mellitus type 1 and 2 and in other monogenetic forms of diabetes $[13,14]$. In WS, functional WFS1 protein deficiency alters IP3R-mediated ER calcium release, leading to disruption of cytoplasmic calcium homeostasis [15]. Also, calpain-2, a calciumdependent proapoptotic cellular protease, may be pivotal in ER stress-induced apoptosis through increased cytoplasmic calcium levels [16-18]. Overactivation of latter is also thought to contribute to pancreatic $\beta$-cell dysfunction and apoptosis in Type 2 diabetes mellitus and WS [17,19].

\section{Conclusion}

To conclude, the above two cases emphasize the phenotypic variability of wolfram syndrome. It can present at any age and with many features. Both of the above cases presented with only two features, DM and optic atrophy. It is recommended to screen for diabetes insipidus and do ophthalmologic examination in all patients of type 1 diabetes mellitus. A high index of clinical suspicion is required in all cases of type 1 diabetes and ocular findings. Genetic mutation analysis is necessary for diagnosis and carrier detection.

\section{References}

1. Wolfram DJ, Wagener HP (1938) Diabetes mellitus and simple optic atrophy among siblings: report of four cases. Mayo Clin Proc 1: 715718.

2. Barrett TG, Bundey SE, Macleod AF (1995) Neurodegeneration and diabetes: UK nationwide study of Wolfram (DIDMOAD) syndrome. Lancet 346(8988): 1458-1463.

3. Medlej R, Wasson J, Baz P, Azar S, Salti I, et al. (2004) Diabetes mellitus and optic atrophy: A study of Wolfram syndrome in the Lebanese population. J Clin Endocrinol Metab 89(4): 1656-1661.

4. Chaussenot A, Bannwarth S, Rouzier C, Vialettes B, Mkadem SA, et al. (2011) Neurologic features and genotype-phenotype correlation in Wolfram syndrome. Ann Neurol 69(3): 501-508.

5. Swift RG, Sadler DB, Swift M (1990) Psychiatric findings in Wolfram syndrome homozygotes. Lancet 336(8716): 667-669.

6. Urano F (2016) Wolfram Syndrome: Diagnosis, Management, and Treatment. Curr Diab Rep 16(1): 6.

7. Kumar S (2010) Wolfram syndrome: important implications for pediatricians and pediatric endocrinologists. Pediatr Diabetes 11(1): 28-37.

8. Medlej R, Wasson J, Baz P, Azar S, Salti I, et al. (2004) Diabetes mellitus and optic atrophy: a study of Wolfram syndrome in the Lebanese population. J Clin Endocrinol Metab 89(4): 1656-1661.

9. de Heredia ML, Clèries R, Nunes V (2013) Genotypic classification of patients with Wolfram syndrome: Insights into the natural history of the disease and correlation with phenotype. Genet Med 15(7): 497506.

10. Cano A, Molines L, Valéro R, Simonin G, Paquis-Flucklinger V, et al. (2007) Microvascular diabetes complications in Wolfram syndrome (diabetes insipidus, diabetes mellitus, optic atrophy, and deafness [DIDMOAD]): an age- and duration-matched comparison with common type 1 diabetes. Diabetes Care 30(9): 2327-2330. 
11. Inoue H, Tanizawa Y, Wasson J, Behn P, Kalidas K et al. (1998) A gene encoding a transmembrane protein is mutated in patients with diabetes mellitus and optic atrophy (Wolfram syndrome). Nat Genet 20(2): 143-8.

12. Strom TM, Hörtnagel K, Hofmann S, Gekeler F, Scharfe C, et al. (1998) Diabetes insipidus, diabetes mellitus, optic atrophy and deafness (DIDMOAD) caused by mutations in a novel gene (wolframin) coding for a predicted transmembrane protein. Hum Mol Genet 7(13): 20212028.

13. Ariyasu D, Yoshida H, Hasegawa Y (2017) Endoplasmic reticulum (Er) stress and endocrine disorders," International Int J Mol Sci 18(2).

14. Støy J, Edghill EL, Flanagan SE, Ye H, Paz VP, et al. (2007) Insulin gene mutations as a cause of permanent neonatal diabetes. Proc Natl Acad Sci USA 104(38): 15040-15044.

15. Cagalinec M, Liiv M, Hodurova Z, Hickey MA, Vaarmann A et al. (2016) Role of mitochondrial dynamics in neuronal development: mechanism for wolfram syndrome. PLoS Biol 14(7): e100251.
16. Tan Y, Dourdin N, Wu C, De Veyra T, Elce JS, et al. (2006) Ubiquitous calpains promote caspase-12 and JNK activation during endoplasmic reticulum stress-induced apoptosis. J Biol Chem 281(23): 1601616024.

17. Huang CJ, Gurlo T, Haataja L, Costes S, Daval M, et al. (2010) Calciumactivated calpain-2 is a mediator of beta cell dysfunction and apoptosis in type 2 diabetes. J Biol Chem 285(1): 339-348

18. Nakagawa T, Yuan J (2000) Crosstalk between two cysteine protease families: activation of caspase-12 by calpain in apoptosis. J Cell Biol 150(4): 887-894.

19. Hara T, Mahadevan J, Kanekura K, Hara M, Lu S, et al. (2014) Calcium efflux from the endoplasmic reticulum leads to $\beta$-cell death. Endocrinology 155(3): 758-768
This work is licensed under Creative

Commons Attribution 4.0 Licens

DOI: 10.19080/AJPN.2019.08.555789

\section{Your next submission with Juniper Publishers will reach you the below assets}

- Quality Editorial service

- Swift Peer Review

- Reprints availability

- E-prints Service

- Manuscript Podcast for convenient understanding

- Global attainment for your research

- Manuscript accessibility in different formats

( Pdf, E-pub, Full Text, Audio)

- Unceasing customer service

Track the below URL for one-step submission https://juniperpublishers.com/online-submission.php 